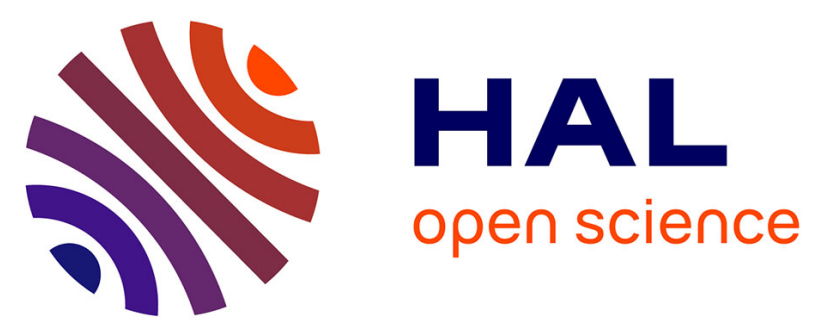

\title{
Are somatostatin and cortistatin two siblings in regulating endocrine secretions? work ahead
}

\author{
Manuel D. Gahete, Mario Durán-Prado, Raúl M. Luque, Antonio J. \\ Martínez-Fuentes, Rafael Vázquez-Martínez, María M. Malagón, Justo P. \\ Castaño
}

\section{To cite this version:}

Manuel D. Gahete, Mario Durán-Prado, Raúl M. Luque, Antonio J. Martínez-Fuentes, Rafael VázquezMartínez, et al.. Are somatostatin and cortistatin two siblings in regulating endocrine secretions? work ahead. Molecular and Cellular Endocrinology, 2008, 286 (1-2), pp.128. 10.1016/j.mce.2007.11.013 . hal-00531964

\section{HAL Id: hal-00531964 \\ https://hal.science/hal-00531964}

Submitted on 4 Nov 2010

HAL is a multi-disciplinary open access archive for the deposit and dissemination of scientific research documents, whether they are published or not. The documents may come from teaching and research institutions in France or abroad, or from public or private research centers.
L'archive ouverte pluridisciplinaire HAL, est destinée au dépôt et à la diffusion de documents scientifiques de niveau recherche, publiés ou non, émanant des établissements d'enseignement et de recherche français ou étrangers, des laboratoires publics ou privés. 


\section{Accepted Manuscript}

Title: Are somatostatin and cortistatin two siblings in regulating endocrine secretions? In vitro work ahead

Authors: Manuel D. Gahete, Mario Durán-Prado, Raúl M.

Luque, Antonio J. Martínez-Fuentes, Rafael

Vázquez-Martínez, María M. Malagón, Justo P. Castaño

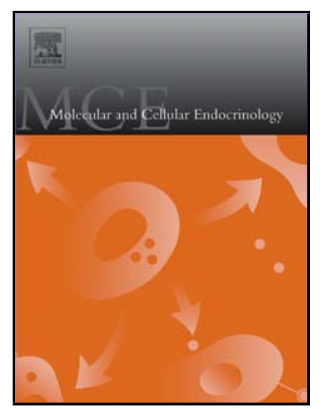

PII:

S0303-7207(07)00431-5

DOI: doi:10.1016/j.mce.2007.11.013

Reference: MCE 6758

To appear in: $\quad$ Molecular and Cellular Endocrinology

Received date: $\quad 20-10-2007$

Revised date: $\quad 17-11-2007$

Accepted date: $\quad 17-11-2007$

Please cite this article as: Gahete, M.D., Durán-Prado, M., Luque, R.M., MartínezFuentes, A.J., Vázquez-Martínez, R., Malagón, M.M., Castaño, J.P., Are somatostatin and cortistatin two siblings in regulating endocrine secretions? In vitro work ahead, Molecular and Cellular Endocrinology (2007), doi:10.1016/j.mce.2007.11.013

This is a PDF file of an unedited manuscript that has been accepted for publication. As a service to our customers we are providing this early version of the manuscript. The manuscript will undergo copyediting, typesetting, and review of the resulting proof before it is published in its final form. Please note that during the production process errors may be discovered which could affect the content, and all legal disclaimers that apply to the journal pertain. 


\title{
Are somatostatin and cortistatin two siblings in regulating endocrine secretions? In vitro work ahead.
}

\author{
Manuel D. Gahete", Mario Durán-Prado\#, Raúl M. Luque, Antonio J. Martínez-Fuentes, \\ Rafael Vázquez-Martínez, María M. Malagón, and Justo P. Castaño*
}

Department of Cell Biology, Physiology and Immunology. University of Cordoba, E-14004 Cordoba, Spain

\# These authors equally contributed to this work.

Short title: in vitro somatostatin and cortistatin actions

Keywords: cortistatin, somatostatin, sst receptors, pituitary, in vitro, endocrine, tumors, pancreas, thyroid

* Correspondence should be addressed to Dr. Justo P. Castaño: Department of Cell Biology, Physiology and Immunology, Campus de Rabanales, Edificio Severo Ochoa, Planta 3. University of Córdoba, E-14014 Córdoba, Spain. Phone: + 349572185 94. Fax: +34 9572186 34. E-mail: justo@uco.es 


\section{Abstract}

Somatostatin (SRIF) and cortistatin (CST) are two cyclic peptides sharing remarkable structural, pharmacological and functional similarities. Both peptides bind all somatostatin receptors subtypes (sst1-5) with comparable affinities, which may explain the considerable similitude between their actions, particularly on endocrine targets. However, the expression patterns of both peptides do not overlap in human tissues, and they are regulated by different stimuli, suggesting that SRIF and CST can exert unique roles. In fact, CST can bind other receptors, different to ssts (e.g. ghrelin receptor, GHS-R, and the MrgX2 receptor), which may be involved in those differential actions. In this review, we have summarized the limited knowledge gathered so far regarding the in vitro actions exerted by CST in different endocrine systems under normal and patho-physiological conditions, and have compared them with the well established functions known for SRIF on these systems. Available data suggests that CST substantially reproduces, but not fully mimics the "in vitro" effects of SRIF on pituitary secretions of human and animal models. Conversely, the functions of CST in the majority of peripheral endocrine (and nonendocrine) tissues are still unknown. Notwithstanding this, the differential tissue expression pattern of SRIF, CST and their receptors suggests that CST may act as a mere natural SRIF analogue in a number of tissues but in some endocrine tissues it may play a predominant, unique regulatory role with potential pathophysiological relevance. The challenge is now to find the genuine differences between these seemingly identical endocrine siblings. 


\section{Are SRIF and CST two endocrine siblings?}

More than three decades ago, in the search of a growth hormone $(\mathrm{GH})$ releasing factor, the group of Guillemin isolated and sequenced an ovine hypothalamic tetradecapeptide that displayed the opposite ability: it inhibited GH secretion. Accordingly, this hypothalamic peptide was named Somatotropin Release Inhibiting Factor (SRIF) or somatostatin (Brazeau et al., 1973). Since that time, it has been demonstrated that SRIF is more than a $\mathrm{GH}$-inhibiting factor, which acts as a pleiotropic effector modulating multiple systems by acting on a broad range of tissues, including pancreas, intestinal tract, central nervous system, and immune cells (Patel, 1999; Moller et al., 2003; Olias et al., 2004) .

More recently, use of molecular approaches led to the discovery of a new gene in several species including frog (Tostivint et al., 1996; Conlon et al., 1997), human and rodents (de Lecea et al., 1996), which was predicted to encode a protein related to SRIF. While the frog variant received the name of SRIF-II because of its similarity to SRIF, the elevated expression level of this gene in human cortex inspired its name, cortistatin (CST), in mammals. Further analysis has revealed that these two peptides share a remarkable sequential, structural and functional resemblance. For instance, SRIF and CST are synthesized as a pre-pro-peptide form that yields two different biologically active peptides, SRIF-14 and SRIF-28 in rat and human, and CST-17 (in human) or CST-14 (in rat) and CST-29 (in both species). In human, CST-17 and SRIF-14 share 11 amino acids, including the FWKT motif, which comprises the receptor binding core, as well as the two cysteine residues responsible for their conserved cyclic structure (for review see (Moller et al., 2003), de Lecea in this issue, and Tostivint et al., this issue).

This sequence identity and structural homology between SRIF and CST could explain their close pharmacology. Indeed, CST and SRIF exhibit a comparable 
subnanomolar binding affinity to the family of receptors previously considered to be exclusive for SRIF, the ssts1-sst5, and both peptides possess the same ability to activate these receptors with similar efficiency and potency (Siehler et al, this issue), which could help to explain why both peptides share many actions at different targets (Moller et al., 2003) (Table 1). On the other hand, CST, unlike SRIF, has been reported to displace ghrelin from its binding sites in the human pituitary, which would likely correspond to the ghrelin receptor $1 \mathrm{~A}$ (GHSR-1A) (Deghenghi et al., 2001), and also to bind to the Mrgx2 receptor (Robas et al., 2003), although this receptor seems to be somewhat promiscuous and more specific for proadrenomedullin and its related peptides (Nothacker et al., 2005). Nevertheless, it has been suggested that activation of these non-sst receptors by CST might be involved in the dissimilar or, in some instances, opposite actions that both peptides, CST and SRIF, play in the central nervous system or in immune cells (de Lecea and Castaño, 2006), Delgado et al., this issue. Indeed, whereas CST causes hypo-motility, depresses cortical excitability and increases slow wave sleep without affecting REM sleep, SRIF causes hyper-motility and enhances cortical excitability and REM sleep (de Lecea et al., 1996). Furthermore, CST (but not SRIF) has been reported to be a potential endogenous anti-inflammatory peptide, likely acting through a reduction in the production of inflammatory mediators by endotoxin-activated macrophages (Gonzalez-Rey et al., 2006).

The tissue expression patterns shown by SRIF and CST also suggest that these two peptides could play differential roles. In fact, in silico analysis of SRIF and CST mRNA distribution indicates that while SRIF expression is restricted to pancreas, brain, stomach, kidney, heart, connective and embryonic tissues, CST mRNA has a broader distribution, which overlaps with that of SRIF in those tissues, and also extends to other endocrine and non endocrine organs (Figure 1: obtained and adapted from 
http://www.ncbi.nlm.nih.gov/UniGene). Moreover, it should be noted that although the expression patterns of SRIF and CST overlap in some tissues, this association does not necessarily imply their colocalization at cellular level. Thus, for example, whereas $50 \%$ of brain GABAergic neurons expressing CST also express SRIF, only $25 \%$ of neurons expressing SRIF also co-express CST mRNA (Spier and de Lecea, 2000). The possible presence of both peptides within the same cells in other tissues is still poorly explored, but solving this question will likely help to understand the differential roles exerted by each peptide in their diverse cell targets.

In spite of its broader distribution, which may also suggest a wider array of potential functions, the putative endocrine actions of CST have received hitherto little attention as compared to those investigated and reported earlier for SRIF (Table 1). This might be due, at least in part, to the fact that the majority of the in vivo and in vitro endocrine actions initially assayed for CST closely mimicked those previously reported for SRIF (Spier and de Lecea, 2000; de Lecea and Castaño, 2006; Broglio et al., 2007). However, it has to be emphasized that a thorough understanding of the pathophysiological meaning of this unique couple of related peptides and their family of common receptors will definitely require a careful comparative examination of their actions at different targets. In this scenario, it appears of interest to survey the data gathered to date on the regulatory actions exerted by CST on endocrine secretions both in vivo and in vitro and to analyze them in light of the corresponding available knowledge on SRIF. To this end, the in vivo endocrine actions of CST have been comprehensively reviewed in this same issue Broglio et al., 2007, and in the present review we have focused on the in vitro actions reported to be exerted by CST on endocrine cells as compared to those known to be effected by SRIF. 


\section{Actions of CST and SRIF on GH release from normal and tumoral pituitaries}

There is a wealth of information regarding the actions of SRIF on somatotrope function, including the receptors and signaling mechanisms underlying inhibition of GH release (for review, see (Patel, 1999; Moller et al., 2003; Olias et al., 2004)). On the contrary, few studies have been conducted to examine the in vitro effects of CST on somatotrope function, perhaps because CST was initially regarded as a mere SRIF natural analogue with relatively low levels of expression in the hypothalamus (Spier and de Lecea, 2000). However, the study of the endocrine effects of CST has recently gained more interest, especially in that related to the control of pituitary hormone secretion, and, in particular, that involving GH synthesis and release.

In this regard, Rubinfeld et al. were the first to report that a $10 \mathrm{nM}$ dose of CST-14 consistently inhibits basal $\mathrm{GH}$ secretion from human fetal pituitary cells in culture (Rubinfeld et al., 2006). Surprisingly, this inhibition was stronger than that exerted by equal doses of SRIF in the same cells (Rubinfeld et al., 2006). Conversely, in cultured porcine pituitary cells, CST not only inhibits GHRH-induced GH secretion as could be expected, but closely reproduces the dual, dose-dependent action of SRIF on GH release in these same pituitary cell cultures (Luque et al., 2006). Specifically, whereas high, submicromolar doses of CST abolished GHRH-stimulated GH release as previously reported for SRIF in this and other species, low, subnanomolar concentrations of CST directly stimulated GH release and did not alter the effect of GHRH (Luque et al., 2006), just as reported earlier for SRIF (Ramirez et al., 1997; Ramirez et al., 1998; Ramirez et al., 2002).

Intriguingly, results from the only report available hitherto on the response of rat pituitary cells in culture to CST indicate that whereas SRIF predictably inhibits basal GH release in vitro, CST-14 induces a direct, dose-dependent stimulatory effect on GH 
secretion, reaching a maximum effect after 60 min of treatment (Baranowska et al., 2006). Further studies will be required to confirm this paradoxical action of CST in rats.

In contrast with the seemingly contradictory results reported in mammals, in cultures of frog pituitary cells both SS1, which corresponds to mammalian SRIF-14, and SS2, the counterpart of mammalian CST, dose-dependently inhibited GHRH-stimulated, although not basal, GH release (Jeandel et al., 1998).

The in vitro actions of CST on human pituitary somatotropic tumors, a classic target for treatment with somatostatin analogues, have also been explored recently. Specifically, the effect of CST on basal and GHRH-stimulated GH secretion was studied in human $\mathrm{GH}$ secreting pituitary adenomas, including GH and mixed GH-PRL (Rubinfeld et al., 2006) where SRIF and its synthetic analogues have long been known to act as potent inhibitors (Moller et al., 2003). In particular, CST was found to effectively inhibit spontaneous $\mathrm{GH}$ release in six of the $13(\sim 50 \%) \mathrm{GH}$-secreting adenomas as well as in two of the three ( $65 \%)$ mixed GH-PRL adenomas tested. Nevertheless, it should be noted that, depending of the pituitary adenoma tested, the efficacy of CST to inhibit GH release was variable when compared to that elicited in parallel by SRIF, octreotide and specific analogs for sst2 and sst5. In addition, CST also suppressed GHRH- and a ghrelin analogstimulated $\mathrm{GH}$ release in cell cultures of one $\mathrm{GH}$-secreting adenoma (Rubinfeld et al., 2006). Thus, although CST seems to act, by and large, as a natural SRIF analogue in regulating $\mathrm{GH}$ release from somatotropes, their actions are not always identical, thereby suggesting that a distinct set of receptor subtypes and/or molecular mechanisms can be differentially activated by these two peptides to finely tune the response of somatotropes under certain circumstances. Moreover, in view of the possible pathophysiological relevance of these differences, the study of those mechanisms deserves further attention. 


\section{Other SRIF actions on normal and tumoral pituitary cells}

Although the somatotrope constitutes the primary cell target for SRIF in the pituitary, it has been reported that all the other endocrine cell types in this gland express somatostatin receptors and that their hormonal secretory activity can be sensitive to the inhibitory action of SRIF, although the particular type of sst involved and the sensitivity to SRIF varies largely depending on the cell type, species, and physiological situation considered (Patel, 1999; Moller et al., 2003).

Actions on lactotropes: SRIF has been shown to inhibit prolactin release in vitro from fetal human pituitary cells (Shimon et al., 1997), and, in earlier studies, from rat (Enjalbert et al., 1982) and fish pituitary cells (Grau et al., 1987). On the contrary, the potential inhibitory effect of CST on prolactin release under normal conditions has not been reported hitherto. Similarly, CST has been found to exert a suppressive effect on PRL secretion in most prolactinomas and somato-prolactinomas, being sst5 the main receptor involved in this inhibitory action (Rubinfeld et al., 2006).

Actions on corticotropes: SRIF has long been known to be able to negatively regulate $\mathrm{ACTH}$ secretion in vitro (Luque et al., 2006). In contrast, no data regarding the capacity of CST to regulate the secretion from corticotropes is available yet, despite recent pieces of evidence that point out the interest of comparatively analyzing the effects of both peptides. Specifically, several studies have recently helped to identify the major components involved in the response of corticotropes to SRIF, specially the receptor subtype sst5, and are also elucidating the mechanisms that may enable a pharmacological treatment of excess ACTH release from corticotropinoma cells causing Cushing's disease (e.g. using sst5-preferred analogues like SOM230, for review see Hofland et al, this issue and Schmid, this issue). Very recently, CST has been reported to display a similar strong 
inhibitory effect than SRIF on the ACTH and cortisol hypersecretion in patients with Cushing's disease (Giordano et al., 2007), although the precise, central (CNS) and/or direct (pituitary) mechanisms employed by CST to exert these actions are not known yet, thereby emphasizing the interest in exploring the in vitro actions of CST on these cells.

Actions on gonadotropes: SRIF has rarely been found to modulate normal gonadotrope function in vitro. Thus, an isolated study on male rat anterior pituitary cells in culture showed that SRIF did not affect basal release of either LH or FSH, whereas it suppressed LHRH-induced release of LH, but not that of FSH (Yu et al., 1997). On the other hand, several studies have demonstrated that SRIF does inhibit gonadotropin release from human pituitary adenomas (both clinically nonfunctioning adenomas and somatotrope adenomas co-secreting the alpha-subunit). Specifically, SRIF suppressed gonadotropin secretion in $60 \%$ of $\mathrm{FSH}$-producing tumors and $30 \%$ of $\mathrm{LH}$-producing tumors, indicating that SRIF inhibits in vitro intact glycoprotein or free subunit secretion in the majority of both tumor types (Klibanski et al., 1991). Similarly, Saveanu et al. reported that SRIF analogues inhibited secretion of LH alpha-subunit in $33 \%$ of cultured cells obtained from a macroadenoma (Saveanu et al., 2001). More recently, use of receptorspecific somatostatin analogs on clinically nonfunctioning pituitary adenoma cells cultured in vitro indicated that the regulation of alpha-subunit secretion by SRIF is mediated through the subtypes sst2A, sst3 and sst5 (Pawlikowski et al., 2007). Taken together, results from these and other reports suggest that although the overall efficacy of SRIF analogues on gonadotrope adenomas is only partial, its potential therapeutic use in this type of tumors deserves attention. In line with this, it is important to note that the direct actions of CST on gonadotropin secretion, either normal or in tumors, have not been reported hitherto, and that their study may shed light on this issue. 
Actions on thyrotropes: SRIF has also been reported to inhibit stimulated thyrotropin release in vitro from fetal human pituitary cells (Shimon et al., 1997), as well as in cultures of pituitary cells from rats (Dieguez et al., 1984), birds (Geris et al., 2003) and amphibia (Table 1). In fact, in this latter species, it has been demonstrated that both SS1 (i.e. SRIF) and SS2 (i.e. the amphibian CST) inhibited TSH release induced by PACAP-38 but did not alter spontaneous (basal) TSH secretion, suggesting a similar role of both neurohormones in the regulation of thyrotrope function in vitro (Okada et al., 2006).

When viewed together, the data obtained in normal and tumoral pituitary cells in culture from mammals and non mammalian vertebrates suggest that the pleiotropic regulatory/modulatory capability of SRIF, and possibly of CST, on pituitary cell function could have evolutionary implications, and has definitely pathological and clinical significance. To date, the scarce effects tested for CST on pituitary cell function in vitro (except for somatotropes) reveal minimal differences with those previously observed for SRIF. Thus, it will be necessary to examine in detail those unexplored actions CST to ascertain whether there are unique functions for CST and SRIF in regulating pituitary cell function or whether these two peptides behave as identical, indistinguishable twins for this gland.

\section{Extrapituitary actions of SRIF and CST on endocrine secretions.}

In contrast to the abundant literature regarding SRIF actions in peripheral endocrine organs (for review, see Patel, 1999; Moller et al., 2003; Olias et al., 2004), there are still no reports on the in vitro actions of CST in other endocrine tissues distinct to pituitary (Table 1), despite the potential relevance of that information given that CST mRNA has a broader distribution than SRIF mRNA (Figure 1). 
Pancreatic actions: CST is expressed in the endocrine pancreas (Papotti et al., 2003), where SRIF has long been known to play an important regulatory role. Indeed, pioneer studies showed for instance that SRIF acts as a potent inhibitor of both glucagon and insulin secretion acting directly on rat pancreatic alpha and beta cells (Efendic et al., 1974; Gerich et al., 1975; Brown et al., 1976). In vivo, it has been reported that CST displays the same inhibitory effects than SRIF on insulin secretion in either physiological and pathological conditions (such as patients with acromegaly or prolactinoma) (Grottoli et al., 2006, and Broglio's review in this issue). In recent years, a number of studies have used sst subtype selective agonists and antagonists to delineate the receptors and molecular mechanisms underlying the inhibitory actions of SRIF on insulin and glucagon secretion. Results from these studies, which are exhaustively reviewed by Strowski and Blake in this issue indicate that these multiple ssts would act in concert to convey the inhibitory signal of SRIF on insulin and glucagon release through and action that is species-dependent, and where it is critical the specific combination and the levels of expression of the ssts involved. Specifically, sst2 seems to be the main receptor mediating the inhibitory actions of SRIF in insulin and glucagon in humans, with sst1 and sst5 playing also a role in regulating insulin. In contrast, in rodents, sst5 appear as the predominant receptor mediating SRIF-induced inhibition of insulin release and sst2 seems to mediate glucagon inhibition (Strowski et al., 2000). In this scenario, and considering its local production in the islets, the study of the potential effects of CST on insulin and glucagon release will be of great interest.

Actions on thyroid gland: SRIF has also been reported to act on the thyroid, where it inhibits $\mathrm{TSH}$-stimulated release of $\mathrm{T} 4$, and $\mathrm{T} 3$, as well as that of calcitonin from parafollicular cells (Patel, 1999). Furthermore, recent studies using the human medullary thyroid carcinoma (MTC) TT cell line have shown that the activation of specific ssts by its 
selective ligands regulates diverse cellular processes, including proliferation, calcitonin secretion and RNA synthesis. Specifically, sst2 y sst5 seem to be the main receptors mediating the actions of SRIF on cell proliferation and calcitonin RNA synthesis while SRIF would act through sst1 to inhibit calcitonin release (Zatelli et al., 2002; Zatelli et al., 2002). However, to date no studies have been conducted testing the direct actions of CST on thyroid function.

Actions on other endocrine organs: SRIF has also been shown to be able to regulate in vitro endocrine secretions in other normal or tumoral peripheral organs like ovary and adrenal gland, which could be also potential pathophysiological targets for CST. In the ovary, SRIF acts as regulator of progesterone release. Specifically, SRIF was able to significantly inhibit the basal progesterone release from cultured human granulosa-luteal cells, but not that stimulated by LH (Holst et al., 1995). In the adrenal gland, it has recently been demonstrated that SRIF can also regulate secretion of catecholamines from chromaffin cells. In this case, SRIF does not inhibit but enhances the release of catecholamines induced by a high concentration of acetylcholine in bovine adrenal medullary cells (Ribeiro et al., 2006). However, to date no studies have been conducted testing the direct actions of CST on these organs.

There are a number of additional actions of SRIF related to the control of secretion, proliferation, etc in multiple tissues wherein CST might also play a role. As a relevant example given its therapeutic implications, it can be mentioned that SRIF can regulate ectopic secretions from pathological tissues. Indeed, SRIF regulated GHRH secretion from GHRH-secreting bronchial cancer cell cultures (Zatelli et al., 2005) thorough a mechanism that seems to differentially involve sst2, sst5, and sst1. However an exhaustive description of those additional targets would be out of the scope of this review. 


\section{Concluding remarks}

As stated above, CST substantially reproduces, but not fully mimics the "in vitro" effects of SRIF on those pituitary secretions of human and animal models studied to date. This data would suggest a redundant role for both peptides in regulating endocrine targets. However, the function of CST in the majority of peripheral endocrine (and non-endocrine) tissues is still unknown. Moreover, the differential tissue expression pattern of SRIF and CST suggests that their functions are likely different rather than redundant in those tissues. The use of KO mice models may shed light on this issue. Thus, although earlier reports on SRIF KO female mice CST does not appear to be upregulated to "compensate" the lack of SRIF, a recent report indicates that loss of endogenous SRIF does up-regulate hypothalamic CST expression only in male mice (Luque and Kineman, 2007). These results suggest that CST actions could be gender-dependent in relation to the regulation of the hypothalamus-pituitary unit, a system wherein SRIF has already been shown to be highly dependent on sexual regulation. Accordingly, it would be of great importance to include this variable in the required detailed analysis that is still ahead to definitely establish the role of CST in regulating endocrine secretions. In this scenario, it can be envisioned that CST will act as a mere natural SRIF analogue in a number of tissues where the latter is to play the major role that is already well defined. However, in light of the available information on their distinct distribution, regulation and actions, it seems reasonable to propose that in some endocrine tissues CST may play a predominant, unique regulatory role over SRIF, with potential pathophysiological relevance. The challenge is now to find the genuine differences between these seemingly identical endocrine siblings. 


\section{Acknowledgements}

This work was supported by CVI-139 and CTS-0175 (Plan Andaluz de Investigación, Junta de Andalucía, Spain), BFU2004-03883 and BFU2007-60180/BFI (Ministerio de Educación

y Ciencia, Spain/FEDER) and CIBER Fisiopatología de la Obesidad y Nutrición CB06/03 (Instituto de Salud Carlos III, Ministerio de Sanidad y Consumo) (to M.M.M. and J.P.C.). 


\section{Bibliography}

Baranowska, B., Chmielowska, M., Wolinska-Witort, E., Bik, W., Baranowska-Bik, A. and Martynska, L. (2006) Direct effect of cortistatin on GH release from cultured pituitary cells in the rat. Neuro Endocrinol Lett 27, 153-6.

Brazeau, P., Vale, W., Burgus, R., Ling, N., Butcher, M., Rivier, J. and Guillemin, R. (1973) Hypothalamic polypeptide that inhibits the secretion of immunoreactive pituitary growth hormone. Science 179, 77-9.

Broglio, F., Papotti, M., Muccioli, G. and Ghigo, E. (2007) Brain-gut communication: cortistatin, somatostatin and ghrelin. Trends Endocrinol Metab 18, 246-51.

Brown, M., Rivier, J. and Vale, W. (1976) Biological activity of somatostatin and somatostatin analogs on inhibtion of arginine-induced insulin and glucagon release in the rat. Endocrinology 98, 336-43.

Conlon, J.M., Tostivint, H. and Vaudry, H. (1997) Somatostatin- and urotensin II-related peptides: molecular diversity and evolutionary perspectives. Regul Pept 69, 95-103.

de Lecea, L. and Castaño, J.P. (2006) Cortistatin: not just another somatostatin analog. Nat Clin Pract Endocrinol Metab 2, 356-7.

de Lecea, L., Criado, J.R., Prospero-Garcia, O., Gautvik, K.M., Schweitzer, P., Danielson, P.E., Dunlop, C.L., Siggins, G.R., Henriksen, S.J. and Sutcliffe, J.G. (1996) A cortical neuropeptide with neuronal depressant and sleep-modulating properties. Nature 381, 242-5. 
Deghenghi, R., Papotti, M., Ghigo, E. and Muccioli, G. (2001) Cortistatin, but not somatostatin, binds to growth hormone secretagogue (GHS) receptors of human pituitary gland. J Endocrinol Invest 24, RC1-3.

Dieguez, C., Foord, S.M., Peters, J.R., Hall, R. and Scanlon, M.F. (1984) Interactions among epinephrine, thyrotropin (TSH)-releasing hormone, dopamine, and somatostatin in the control of TSH secretion in vitro. Endocrinology 114, 957-61.

Efendic, S., Luft, R. and Grill, V. (1974) Effect of somatostatin on glucose induced insulin release in isolated perfused rat pancreas and isolated rat pancreatic islets. FEBS Lett 42, 169-72.

Enjalbert, A., Epelbaum, J., Arancibia, S., Tapia-Arancibia, L., Bluet-Pajot, M.T. and Kordon, C. (1982) Reciprocal interactions of somatostatin with thyrotropin-releasing hormone and vasoactive intestinal peptide on prolactin and growth hormone secretion in vitro. Endocrinology 111, 42-7.

Gerich, J.E., Lovinger, R. and Grodsky, G.M. (1975) Inhibition by somatostatin of glucagon and insulin release from the perfused rat pancreas in response to arginine, isoproterenol and theophylline: evidence for a preferential effect on glucagon secretion. Endocrinology 96, 749-54.

Geris, K.L., De Groef, B., Kuhn, E.R. and Darras, V.M. (2003) In vitro study of corticotropin-releasing hormone-induced thyrotropin release: ontogeny and inhibition by somatostatin. Gen Comp Endocrinol 132, 272-7.

Giordano, R., Picu, A., Bonelli, L., Broglio, F., Prodam, F., Grottoli, S., Muccioli, G., Ghigo, E. and Arvat, E. (2007) The activation of somatostatinergic receptors by either 
somatostatin-14 or cortistatin-17 often inhibits ACTH hypersecretion in patients with Cushing's disease. Eur J Endocrinol 157, 393-8.

Gonzalez-Rey, E., Chorny, A., Robledo, G. and Delgado, M. (2006) Cortistatin, a new antiinflammatory peptide with therapeutic effect on lethal endotoxemia. J Exp Med 203, 563-71.

Grau, E.G., Ford, C.A., Helms, L.M., Shimoda, S.K. and Cooke, I.M. (1987) Somatostatin and altered medium osmotic pressure elicit rapid changes in prolactin release from the rostral pars distalis of the tilapia, Oreochromis mossambicus, in vitro. Gen Comp Endocrinol 65, 12-8.

Holst, N., Jacobsen, M.B., Haug, E., Tanbo, T. and Abyholm, T. (1995) Somatostatin in physiological concentrations inhibits basal and enhances luteinizing hormonestimulated progesterone release from human granulosa-luteal cells. Hum Reprod $10,1363-6$.

Jeandel, L., Okuno, A., Kobayashi, T., Kikuyama, S., Tostivint, H., Lihrmann, I., Chartrel, N., Conlon, J.M., Fournier, A., Tonon, M.C. and Vaudry, H. (1998) Effects of the two somatostatin variants somatostatin-14 and [Pro2, Met13]somatostatin-14 on receptor binding, adenylyl cyclase activity and growth hormone release from the frog pituitary. J Neuroendocrinol 10, 187-92.

Klibanski, A., Alexander, J.M., Bikkal, H.A., Hsu, D.W., Swearingen, B. and Zervas, N.T. (1991) Somatostatin regulation of glycoprotein hormone and free subunit secretion in clinically nonfunctioning and somatotroph adenomas in vitro. J Clin Endocrinol Metab 73, 1248-55. 
Luque, R.M., Gahete, M.D., Hochgeschwender, U. and Kineman, R.D. (2006) Evidence that endogenous SST inhibits ACTH and ghrelin expression by independent pathways. Am J Physiol Endocrinol Metab 291, E395-403.

Luque, R.M. and Kineman, R.D. (2007) Gender-dependent role of endogenous somatostatin in regulating growth hormone $(\mathrm{GH})$-axis function in mice. Endocrinology.

Luque, R.M., Peinado, J.R., Gracia-Navarro, F., Broglio, F., Ghigo, E., Kineman, R.D., Malagon, M.M. and Castaño, J.P. (2006) Cortistatin mimics somatostatin by inducing a dual, dose-dependent stimulatory and inhibitory effect on growth hormone secretion in somatotropes. J Mol Endocrinol 36, 547-56.

Moller, L.N., Stidsen, C.E., Hartmann, B. and Holst, J.J. (2003) Somatostatin receptors. Biochim Biophys Acta 1616, 1-84.

Nothacker, H.P., Wang, Z., Zeng, H., Mahata, S.K., O'Connor, D.T. and Civelli, O. (2005) Proadrenomedullin N-terminal peptide and cortistatin activation of MrgX2 receptor is based on a common structural motif. Eur J Pharmacol 519, 191-3.

Okada, R., Yamamoto, K., Ito, Y., Chartrel, N., Leprince, J., Fournier, A., Vaudry, H. and Kikuyama, S. (2006) Effects of pituitary adenylate cyclase-activating polypeptide, vasoactive intestinal polypeptide, and somatostatin on the release of thyrotropin from the bullfrog pituitary. Ann N Y Acad Sci 1070, 474-80.

Olias, G., Viollet, C., Kusserow, H., Epelbaum, J. and Meyerhof, W. (2004) Regulation and function of somatostatin receptors. J Neurochem 89, 1057-91. 
Papotti, M., Tarabra, E., Allia, E., Bozzalla-Cassione, F., Broglio, F., Deghenghi, R., Ghigo, E. and Muccioli, G. (2003) Presence of cortistatin in the human pancreas. J Endocrinol Invest 26, RC15-8.

Patel, Y.C. (1999) Somatostatin and its receptor family. Front Neuroendocrinol 20, 157-98.

Pawlikowski, M., Lawnicka, H., Pisarek, H., Kunert-Radek, J., Radek, M. and Culler, M.D. (2007) Effects of somatostatin-14 and the receptor-specific somatostatin analogs on chromogranin A and alpha-subunit (alpha-SU) release from "clinically nonfunctioning" pituitary adenoma cells incubated in vitro. J Physiol Pharmacol 58, 179-88.

Ramirez, J.L., Castaño, J.P. and Gracia-Navarro, F. (1998) Somatostatin at low doses stimulates growth hormone release from intact cultures of porcine pituitary cells. Horm Metab Res 30, 175-7.

Ramirez, J.L., Gracia-Navarro, F., Garcia-Navarro, S., Torronteras, R., Malagon, M.M. and Castaño, J.P. (2002) Somatostatin stimulates GH secretion in two porcine somatotrope subpopulations through a cAMP-dependent pathway. Endocrinology $143,889-97$.

Ramirez, J.L., Torronteras, R., Castaño, J.P., Sanchez-Hormigo, A., Garrido, J.C., GarciaNavarro, S. and Gracia-Navarro, F. (1997) Somatostatin plays a dual, stimulatory/inhibitory role in the control of growth hormone secretion by two somatotrope subpopulations from porcine pituitary. J Neuroendocrinol 9, 841-8.

Ribeiro, L., Martel, F. and Azevedo, I. (2006) The release of 3H-1-methyl-4phenylpyridinium from bovine adrenal chromaffin cells is modulated by somatostatin. Regul Pept 137, 107-13. 
Robas, N., Mead, E. and Fidock, M. (2003) MrgX2 is a high potency cortistatin receptor expressed in dorsal root ganglion. J Biol Chem 278, 44400-4.

Rubinfeld, H., Hadani, M., Barkai, G., Taylor, J.E., Culler, M.D. and Shimon, I. (2006) Cortistatin inhibits growth hormone release from human fetal and adenoma pituitary cells and prolactin secretion from cultured prolactinomas. J Clin Endocrinol Metab $91,2257-63$.

Saveanu, A., Morange-Ramos, I., Gunz, G., Dufour, H., Enjalbert, A. and Jaquet, P. (2001) A luteinizing hormone-, alpha-subunit- and prolactin-secreting pituitary adenoma responsive to somatostatin analogs: in vivo and in vitro studies. Eur $\mathrm{J}$ Endocrinol $145,35-41$.

Shimon, I., Taylor, J.E., Dong, J.Z., Bitonte, R.A., Kim, S., Morgan, B., Coy, D.H., Culler, M.D. and Melmed, S. (1997) Somatostatin receptor subtype specificity in human fetal pituitary cultures. Differential role of SSTR2 and SSTR5 for growth hormone, thyroid-stimulating hormone, and prolactin regulation. J Clin Invest 99, 789-98.

Spier, A.D. and de Lecea, L. (2000) Cortistatin: a member of the somatostatin neuropeptide family with distinct physiological functions. Brain Res Brain Res Rev $33,228-41$.

Strowski, M.Z., Parmar, R.M., Blake, A.D. and Schaeffer, J.M. (2000) Somatostatin inhibits insulin and glucagon secretion via two receptors subtypes: an in vitro study of pancreatic islets from somatostatin receptor 2 knockout mice. Endocrinology 141, 111-7.

Tostivint, H., Lihrmann, I., Bucharles, C., Vieau, D., Coulouarn, Y., Fournier, A., Conlon, J.M. and Vaudry, H. (1996) Occurrence of two somatostatin variants in the frog 
brain: characterization of the cDNAs, distribution of the mRNAs, and receptorbinding affinities of the peptides. Proc Natl Acad Sci U S A 93, 12605-10.

Yu, W.H., Kimura, M. and McCann, S.M. (1997) Effect of somatostatin on the release of gonadotropins in male rats. Proc Soc Exp Biol Med 214, 83-6.

Zatelli, M.C., Maffei, P., Piccin, D., Martini, C., Rea, F., Rubello, D., Margutti, A., Culler, M.D., Sicolo, N. and degli Uberti, E.C. (2005) Somatostatin analogs in vitro effects in a growth hormone-releasing hormone-secreting bronchial carcinoid. J Clin Endocrinol Metab 90, 2104-9.

Zatelli, M.C., Tagliati, F., Piccin, D., Taylor, J.E., Culler, M.D., Bondanelli, M. and degli Uberti, E.C. (2002) Somatostatin receptor subtype 1-selective activation reduces cell growth and calcitonin secretion in a human medullary thyroid carcinoma cell line. Biochem Biophys Res Commun 297, 828-34.

Zatelli, M.C., Tagliati, F., Taylor, J.E., Piccin, D., Culler, M.D. and degli Uberti, E.C. (2002) Somatostatin, but not somatostatin receptor subtypes 2 and 5 selective agonists, inhibits calcitonin secretion and gene expression in the human medullary thyroid carcinoma cell line, TT. Horm Metab Res 34, 229-33. 


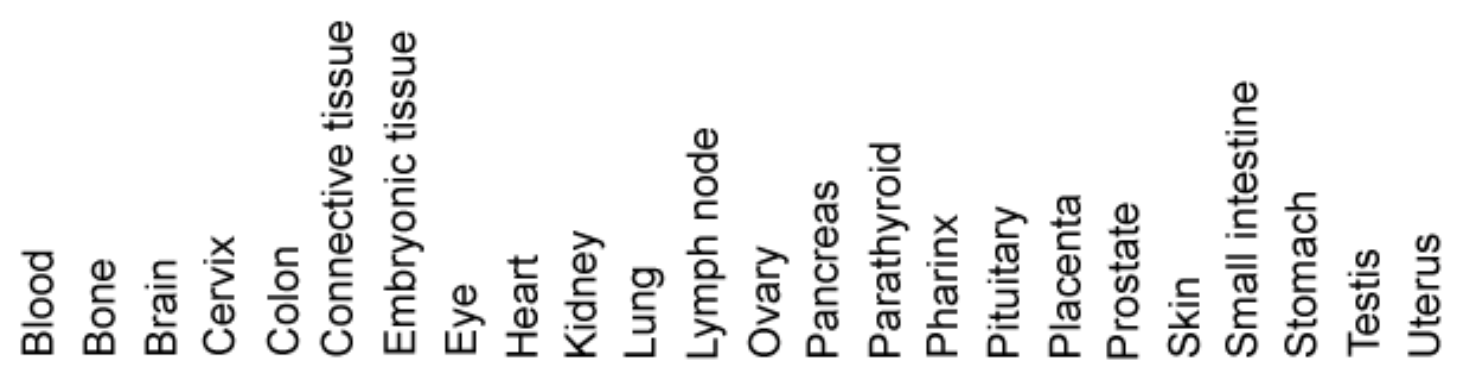

SRIF

CST

Figure 1: Tissue expression pattern of human SRIF and CST. The data is obtained and adapted from UniGene (http://www.ncbi.nlm.nih.gov/UniGene). Relative abundance of the transcripts in each tissue is indicated in different grey intensities where darker means higher expression. 


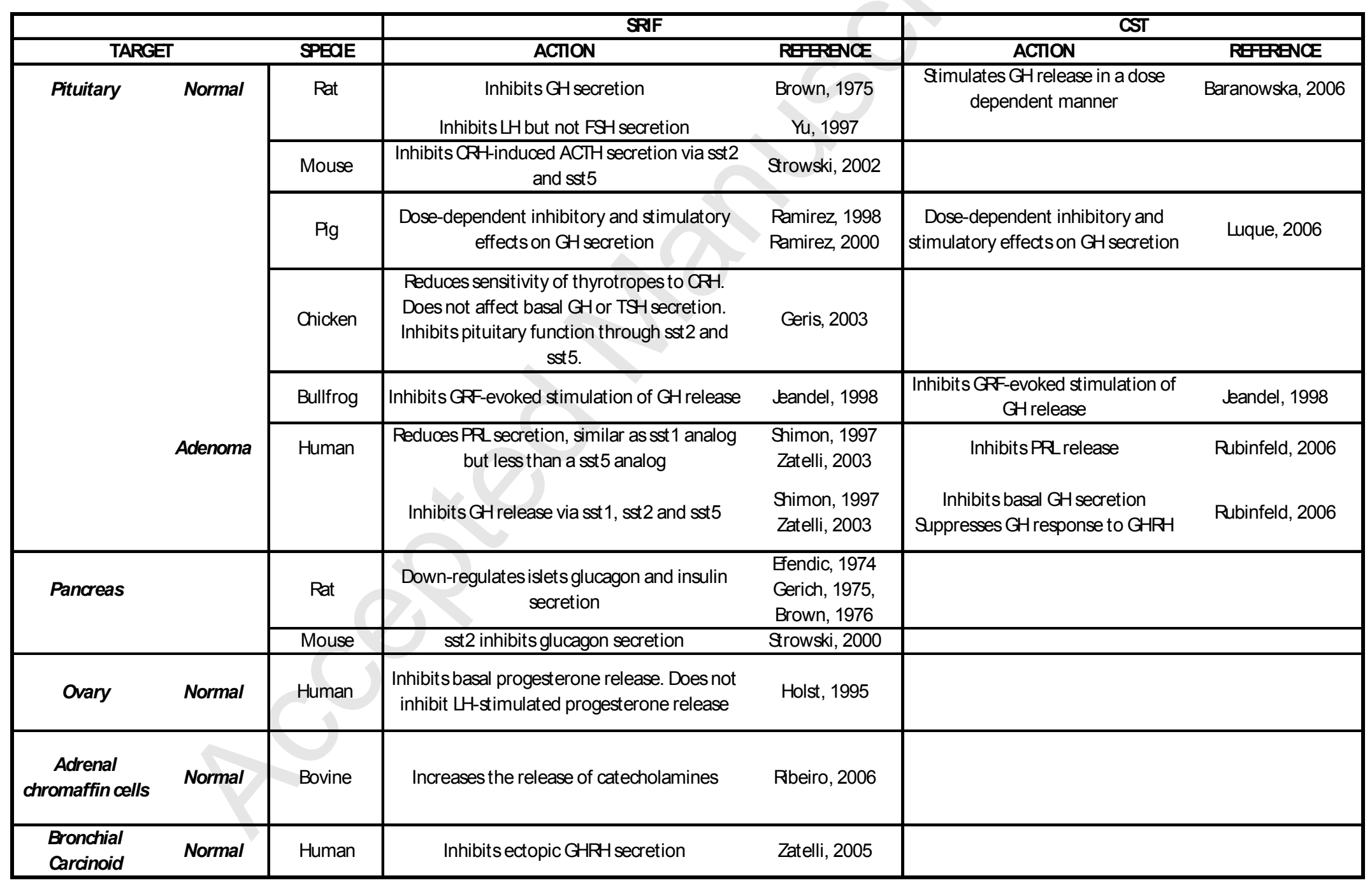

Table 1: Summary of the regulatory actions of SRIF and CST on endocrine secretions in vitro. The table presents some representative examples of the reported effects of these two peptides on endocrine tissues and compares their action where there is data available. 